\title{
Northern Quahog (=Hard Clam) Mercenaria Mercenaria Age At Length Relationships And Growth Patterns In The York River, Virginia 1954 To 1970
}

Juliana Harding

Virginia Institute of Marine Science

Follow this and additional works at: https://scholarworks.wm.edu/vimsarticles

Part of the Marine Biology Commons

\section{Recommended Citation}

Harding, Juliana, "Northern Quahog (=Hard Clam) Mercenaria Mercenaria Age At Length Relationships And Growth Patterns In The York River, Virginia 1954 To 1970" (2007). VIMS Articles. 444.

https://scholarworks.wm.edu/vimsarticles/444 


\title{
NORTHERN QUAHOG (= HARD CLAM) MERCENARIA MERCENARIA AGE AT LENGTH RELATIONSHIPS AND GROWTH PATTERNS IN THE YORK RIVER, VIRGINIA 1954 TO 1970
}

\author{
JULIANA M. HARDING \\ Department of Fisheries Science, Virginia Institute of Marine Science, Gloucester Point, Virginia, 23062
}

\begin{abstract}
Northern quahogs Mercenaria mercenaria were grown in trays suspended in the York River, Virginia from November 1954 (4 months old) to December 1970 (16 years old). Measurements of shell length ( $\mathrm{mm}$ ) were made at least once a year from 1954 to 1970 and measurements of shell width $(\mathrm{mm})$ were made in November 1962 and August 1965 and then once per year from 1967 through 1970. Quahog densities within the trays ranged from $1500 \mathrm{~m}^{-2}$ (November 1954 to October 1955) to $269 \mathrm{~m}^{-2}$ (November 1955 to December 1970). Quahog shell length (mm) increased with age (yr) and was described with a Von Bertalanffy growth model (coefficient of determination $=0.93$ ). Most of the growth in shell length occurred in the first 6 years with clams reaching shell lengths of $58 \mathrm{~mm}$ by November 1960 and maximum shell lengths of 77-84 $\mathrm{mm}$ by 1963 (age 9). Shell length:shell width relationships were similar for tray held and wild quahogs collected from the York River during 1967 to 1970. The observed annual shell length growth increment decreased exponentially with quahog age. Standardized shell length growth index (SGI) values for 11 of the 15 years for which data are available describe better than expected quahog growth trends although there was no clear relationship between SGI and average annual surface temperature or average growth period (water temperature $>7^{\circ} \mathrm{C}$, typically March to November) surface temperature in the York River between 1955 and 1967.
\end{abstract}

KEY WORDS: Northern quahog, Mercenaria mercenaria, hard clam, age at length relationship, growth, annual growth increment, water temperature

\section{INTRODUCTION}

Northern quahog Mercenaria mercenaria are an ecologically and commercially valuable species in the lower Chesapeake Bay. Historically, quahogs were a benthic dominant species in sandy mud habitats with salinities less than 10 ppt (Roegner \& Mann 1991). Although oyster (Crassostrea virginica) population levels in the lower Chesapeake Bay were decimated during the period 1950-1972 by a combination of disease, abnormal environmental conditions, and fishing pressure (Andrews 1996, Burreson \& Calvo 1996), northern quahog populations remained relatively stable in terms of abundance and demographics through the early 1970s (Loesch \& Haven 1973a, 1973b). While northern quahog populations in the lower Chesapeake Bay currently support commercial fishing activity, population density levels in 2001 to 2002 (Mann et al. 2005) are an order of magnitude lower than those observed by Haven et al. (1973) and Loesch \& Haven (1973b). Modern Chesapeake Bay quahog populations and habitat are threatened by continued watershed degradation, shoreline development, dredging activity for shipping channels and dock access, as well as increased fishing pressure concurrent with the decline of the oyster industry.

Examination of historic Chesapeake Bay data describing northern quahog age at length relationships and growth trajectories provides baseline information to place modern information in context. In the absence of basic descriptive information from historic populations grown in less disturbed habitats, appropriate baselines or barometers to guide modern restoration, management, and conservation practices are lacking. The objective of this paper is to quantitatively describe age at length relationships and growth patterns for northern quahogs Mercenaria mercenaria grown in experimental trays in the York River, Virginia from 1954 through 1970.

E-mail: jharding@vims.edu
Haven and Andrews (1957) present volume and yield information for this same series of $M$. mercenaria from November 1954 through October 1956 when clams reached market size but do not describe age at length relationships or growth patterns for this time frame. The methods described later are summarized from Haven and Andrews (1957) and field notes by Mr. Dexter Haven and Mr. James Whitcomb that were archived with the original project datasheets. The analyses herein rely on the handwritten data sheets from 1954 to 1970 that were archived in the VIMS Molluscan Ecology program by Mr. Reinaldo Morales-Alamo. Data were entered into databases by the author.

\section{MATERIALS AND METHODS}

Northern quahogs (hard clams) were acquired from the Milford Laboratory, New Haven, CT in November 1954 by Dr. Jay Andrews and Mr. Dexter Haven. These cultured clams were the progeny of Long Island broodstock (Haven \& Andrews 1957) and were approximately 4 months old in November 1954 at the time of shipment to the Virginia Institute of Marine Science (VIMS) in Gloucester Point, Virginia. On arrival at VIMS, quahogs were deployed in the lower York River in wooden trays filled with sand/mud suspended off the bottom at densities of 145 clams per $0.23 \mathrm{~m} \times 0.41 \mathrm{~m} \times 0.1 \mathrm{~m}$ section (Haven \& Andrews 1957) or approximately $1500 \mathrm{~m}^{-2}$. In October 1955, 25 clams were individually numbered and replaced in the suspended trays at densities of 25 per $0.23 \mathrm{~m} \times 41 \mathrm{~m} \times 0.1$ $\mathrm{m}$ section (Haven \& Andrews 1957) or $269 \mathrm{~m}^{-2}$. Clams remained in these trays at these approximate densities until December 1970. Clam shell length (mm, SL) and the maximum dimension anterior to posterior, was measured at deployment (November 1954), once a month during the growing seasons (1954 to 1956 , Haven \& Andrews 1957) and at least once a year from 1957 through 1970. Shell width or thickness, the dimension across the hinge on a lateral axis (mm), was measured in November 1962 and August 1965 and then once per year from 1967 through 1970. 


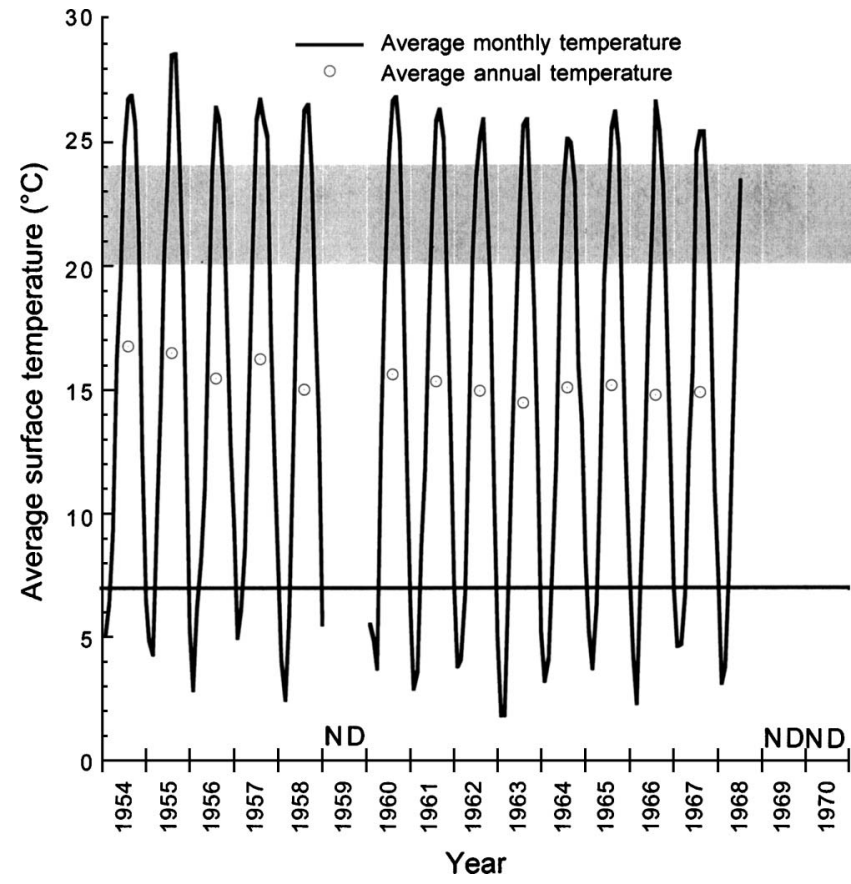

Figure 1. Average monthly surface water temperatures from 1954 through 1968 measured at Gloucester Point, Virginia. Data are from United States Department of Commerce publications (1960, 1968, 1973). "ND" indicates years in which no data were available. The shaded box indicates water temperatures $20^{\circ} \mathrm{C}$ to $24^{\circ} \mathrm{C}$ (optimal temperature for growth of northern quahogs, Ansell 1968, Grizzle et al. 2001). The solid black line at $7^{\circ} \mathrm{C}$ indicates the lower thermal limit for northern quahog shell growth (Ansell 1968, Grizzle et al. 2001).

Monthly average surface water temperatures recorded at Gloucester Point, Virginia (US Department of Commerce 1960, 1968, 1973) during the study period are presented. Annual average surface water temperatures ( \pm standard error of the mean) were calculated for years with at least 11 months of data available. Annual growth period surface water temperatures ( \pm standard error of the mean) were calculated for years with at least 8 months of data for months when recorded water temperatures were above $7^{\circ} \mathrm{C}$, the lower thermal limit for M. mercenaria growth (Ansell 1968, Grizzle et al. 2001), which typically occur from March through December at Gloucester Point, Virginia. Water temperatures of $31^{\circ} \mathrm{C}$ or greater, the upper thermal limit for M. mercenaria growth (Ansell 1968, Grizzle et al. 2001), were not observed at Gloucester Point, Virginia during the period 1954 to 1970.

\section{Data Analyses}

A Von Bertalanffy model was used to describe age (years) at shell length $(\mathrm{mm})$ data for these tray grown northern quahogs. This model describes maximum growth and does not assume rotational symmetry about an inflection point. It has been used previously to describe the growth of northern quahogs (Jones et al. 1989, Jones et al. 1990, Devillers et al. 1998). The model equation is:

$$
\mathrm{SL}_{\mathrm{t}}=\mathrm{SL}_{\max }\left(1-\mathrm{e}^{-\mathrm{k}\left(\mathrm{t}-\mathrm{t}_{0}\right)}\right)
$$

where $\mathrm{SL}_{\mathrm{t}}$ is the shell length at time $\mathrm{t}, \mathrm{SL}_{\max }$ is the maximum or asymptotic shell length, $\mathrm{t}_{0}$ is the size at time 0 , and $\mathrm{k}$ is a rate constant.

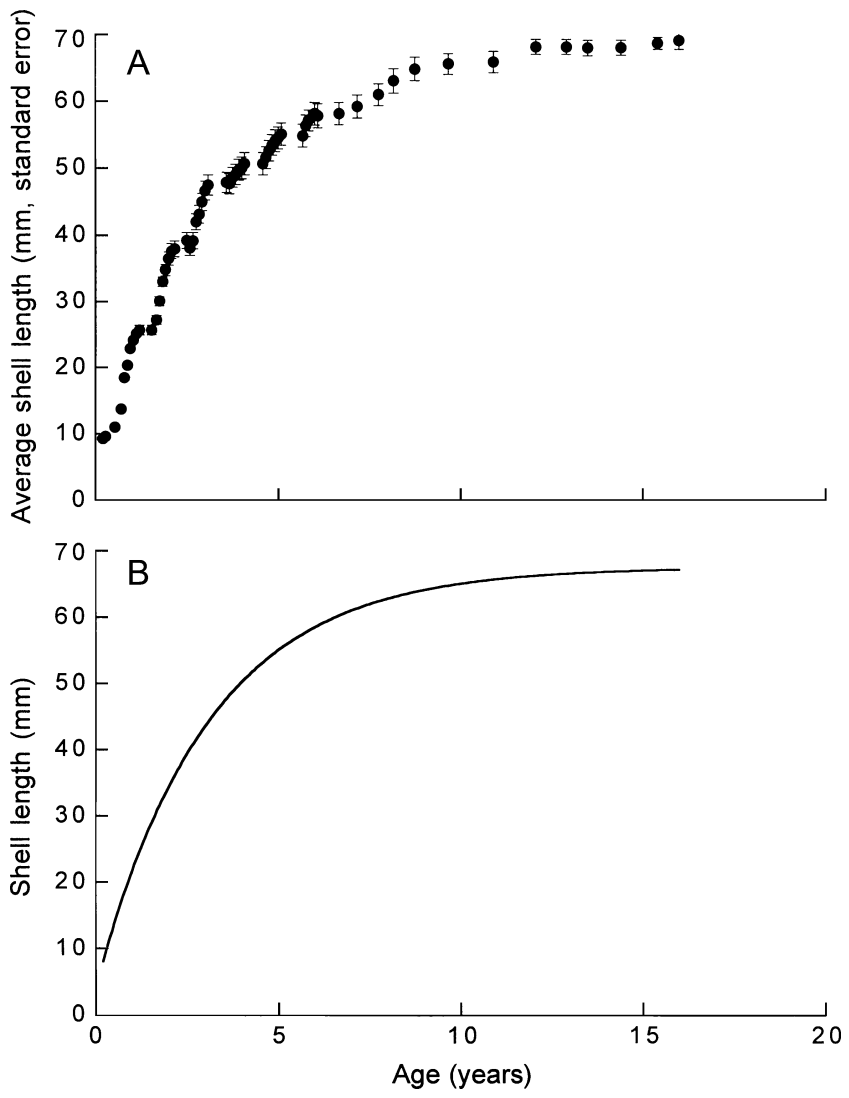

Figure 2. SL at age relationships for York River, Virginia northern quahogs grown in trays 1954 to 1970 including (A) average measured SL ( \pm standard error of the mean) and (B) fitted Von Bertalanffy growth model. Quahogs were kept at abundances of 125-145 clams tray ${ }^{-1}$ from October 1954 through October 1955 and 25 clams tray $^{-1}$ or less from November 1955 through 1970. Von Bertalanffy model parameters are given in text.

Survivorship was estimated for high (125-145 quahogs per tray, November 1954 to October 1955) and low (16-25 quahogs per tray, November 1955 to December 1970) by dividing the number of live quahogs at a measurement period by the total number of quahogs present in November 1954 (high density) and November 1955 (low density).

The relationship between shell length $(\mathrm{mm})$ and shell width $(\mathrm{mm})$ was described for a size range of clams held in trays (this study) using a linear relationship. For comparative purposes, the relationship between shell length and shell width measurements was calculated using measurements made on wild northern quahogs collected during York River stock assessment surveys in the period 1967 to 1972 described by Haven et al. (1973).

The annual shell length growth increment $\left(\mathrm{mm} \mathrm{yr}^{-1}\right)$ was calculated for each of the 25 numbered clams. The average size (9.2 $\mathrm{mm} \mathrm{SL}$ ) for all 145 clams in November 1954 was used as the size at age 0 for the 25 clams that were individually numbered in October 1955 and followed until December 1970. Annual shell length growth increment calculations for age 1 and older used the individual shell length measurements recorded for each clam.

Jones et al. (1989) used the first derivative of the von Bertalanffy function to predict the expected ontogenetic 
TABLE 1.

Summary of northern quahog growth and survivorship observed in trays deployed in the lower York River, Virginia from November 1954 through December 1970. SEM = standard error of the mean. Quahog abundance was changed on November 22, 1955 from 125+ individuals per tray to 25 marked individuals per tray, thus survivorship estimates after November 22,1955 use 25 quahogs as a starting value instead of the original 125-145 clams.

\begin{tabular}{|c|c|c|c|c|c|c|c|}
\hline Date & Age (yr) & Number Alive & Minimum SL & Maximum SL & Average SL & SEM SL & Survivorship (\%) \\
\hline $11 / 16 / 54$ & 0.21 & 145 & 6 & 13 & 9.23 & 0.12 & 100 \\
\hline $12 / 16 / 54$ & 0.29 & 145 & 7 & 13 & 9.58 & 0.11 & 100 \\
\hline $3 / 16 / 55$ & 0.54 & 144 & 7 & 15 & 11.01 & 0.14 & 99 \\
\hline $5 / 18 / 55$ & 0.71 & 142 & 9 & 18 & 13.73 & 0.15 & 97 \\
\hline $6 / 17 / 55$ & 0.79 & 134 & 12 & 24 & 18.45 & 0.18 & 92 \\
\hline $7 / 14 / 55$ & 0.88 & 140 & 12 & 25 & 20.34 & 0.18 & 96 \\
\hline $8 / 15 / 55$ & 0.96 & 137 & 14 & 30 & 22.87 & 0.23 & 94 \\
\hline $9 / 20 / 55$ & 1.04 & 131 & 14 & 32 & 24.16 & 0.29 & 90 \\
\hline $10 / 20 / 55$ & 1.13 & 129 & 15 & 34 & 25.12 & 0.34 & 88 \\
\hline $11 / 22 / 55$ & 1.21 & 25 & 19 & 33 & 25.64 & 0.74 & 100 \\
\hline $3 / 15 / 56$ & 1.54 & 25 & 19 & 32 & 25.64 & 0.74 & 100 \\
\hline $5 / 15 / 56$ & 1.67 & 24 & 22 & 34 & 27.21 & 0.67 & 96 \\
\hline $6 / 15 / 56$ & 1.75 & 24 & 25 & 37 & 30.04 & 0.68 & 96 \\
\hline $7 / 16 / 56$ & 1.83 & 24 & 28 & 39 & 32.96 & 0.7 & 96 \\
\hline $8 / 15 / 56$ & 1.92 & 24 & 28 & 43 & 34.75 & 0.87 & 96 \\
\hline $9 / 14 / 56$ & 2 & 24 & 28 & 47 & 36.46 & 1.02 & 96 \\
\hline $10 / 16 / 56$ & 2.08 & 24 & 28 & 48 & 37.58 & 1.15 & 96 \\
\hline $11 / 14 / 56$ & 2.17 & 24 & 28 & 49 & 37.92 & 1.18 & 96 \\
\hline $3 / 15 / 57$ & 2.5 & 24 & 30 & 51 & 39.17 & 1.2 & 96 \\
\hline $4 / 15 / 57$ & 2.58 & 24 & 28 & 49 & 38.08 & 1.18 & 96 \\
\hline $5 / 14 / 57$ & 2.67 & 24 & 28 & 51 & 39.13 & 1.21 & 96 \\
\hline $6 / 14 / 57$ & 2.75 & 24 & 29 & 54 & 41.95 & 1.2 & 96 \\
\hline $7 / 15 / 57$ & 2.83 & 24 & 29 & 55 & 43.13 & 1.32 & 96 \\
\hline $8 / 15 / 57$ & 2.92 & 23 & 33 & 58 & 44.96 & 1.28 & 92 \\
\hline $9 / 16 / 57$ & 3 & 23 & 33 & 60 & 46.68 & 1.42 & 92 \\
\hline $10 / 10 / 57$ & 3.08 & 23 & 33 & 62 & 47.52 & 1.5 & 92 \\
\hline $4 / 14 / 58$ & 3.58 & 23 & 33 & 62 & 47.91 & 1.51 & 92 \\
\hline $5 / 14 / 58$ & 3.67 & 23 & 34 & 62 & 47.7 & 1.5 & 92 \\
\hline $6 / 16 / 58$ & 3.75 & 23 & 35 & 63 & 48.65 & 1.5 & 92 \\
\hline $7 / 16 / 58$ & 3.83 & 23 & 35 & 64 & 49.13 & 1.54 & 92 \\
\hline $8 / 19 / 58$ & 3.92 & 23 & 35 & 65 & 49.78 & 1.57 & 92 \\
\hline $9 / 15 / 58$ & 4 & 23 & 35 & 66 & 50.09 & 1.61 & 92 \\
\hline $10 / 15 / 58$ & 4.08 & 23 & 36 & 67 & 50.7 & 1.65 & 92 \\
\hline $4 / 15 / 59$ & 4.58 & 23 & 35 & 67 & 50.7 & 1.65 & 92 \\
\hline $5 / 14 / 59$ & 4.67 & 23 & 37 & 68 & 51.61 & 1.63 & 92 \\
\hline $6 / 22 / 59$ & 4.75 & 23 & 38 & 68 & 52.65 & 1.54 & 92 \\
\hline $7 / 15 / 59$ & 4.83 & 23 & 40 & 68 & 53.48 & 1.53 & 92 \\
\hline $8 / 17 / 59$ & 4.92 & 23 & 39 & 71 & 54.13 & 1.62 & 92 \\
\hline $9 / 17 / 59$ & 5 & 23 & 39 & 72 & 54.55 & 1.64 & 92 \\
\hline $10 / 16 / 59$ & 5.08 & 23 & 39 & 72 & 55.1 & 1.67 & 92 \\
\hline $5 / 16 / 60$ & 5.67 & 23 & 41 & 73 & 54.87 & 1.68 & 92 \\
\hline $6 / 16 / 60$ & 5.75 & 23 & 42 & 73 & 56.36 & 1.62 & 92 \\
\hline $7 / 16 / 60$ & 5.83 & 23 & 43 & 74 & 57.17 & 1.57 & 92 \\
\hline $9 / 16 / 60$ & 6 & 23 & 44 & 76 & 58.17 & 1.69 & 92 \\
\hline $10 / 18 / 60$ & 6.08 & 23 & 43 & 76 & 57.81 & 1.8 & 92 \\
\hline $5 / 25 / 61$ & 6.67 & 23 & 44 & 76 & 58.17 & 1.65 & 92 \\
\hline $11 / 21 / 61$ & 7.17 & 23 & 43 & 77 & 59.26 & 1.72 & 92 \\
\hline $6 / 6 / 62$ & 7.75 & 23 & 44 & 78 & 61 & 1.62 & 92 \\
\hline $11 / 15 / 62$ & 8.17 & 23 & 44 & 83 & 63.1 & 1.83 & 92 \\
\hline $6 / 20 / 63$ & 8.75 & 23 & 46 & 84 & 64.87 & 1.74 & 92 \\
\hline $5 / 12 / 64$ & 9.67 & 20 & 47 & 77 & 65.6 & 1.58 & 80 \\
\hline $8 / 20 / 65$ & 10.92 & 19 & 48 & 77 & 65.89 & 1.59 & 76 \\
\hline $10 / 24 / 66$ & 12.08 & 18 & 55 & 77 & 68.17 & 1.13 & 72 \\
\hline $8 / 28 / 67$ & 12.92 & 18 & 55 & 77 & 68.17 & 1.13 & 72 \\
\hline $4 / 2 / 68$ & 13.5 & 18 & 54.7 & 77.2 & 68.01 & 1.15 & 72 \\
\hline $5 / 21 / 69$ & 14.42 & 18 & 55 & 77 & 68.03 & 1.13 & 72 \\
\hline $5 / 28 / 70$ & 15.42 & 17 & 64 & 76.8 & 68.67 & 0.89 & 68 \\
\hline $12 / 7 / 70$ & 16 & 16 & 54.7 & 78.8 & 69.14 & 1.39 & 64 \\
\hline
\end{tabular}




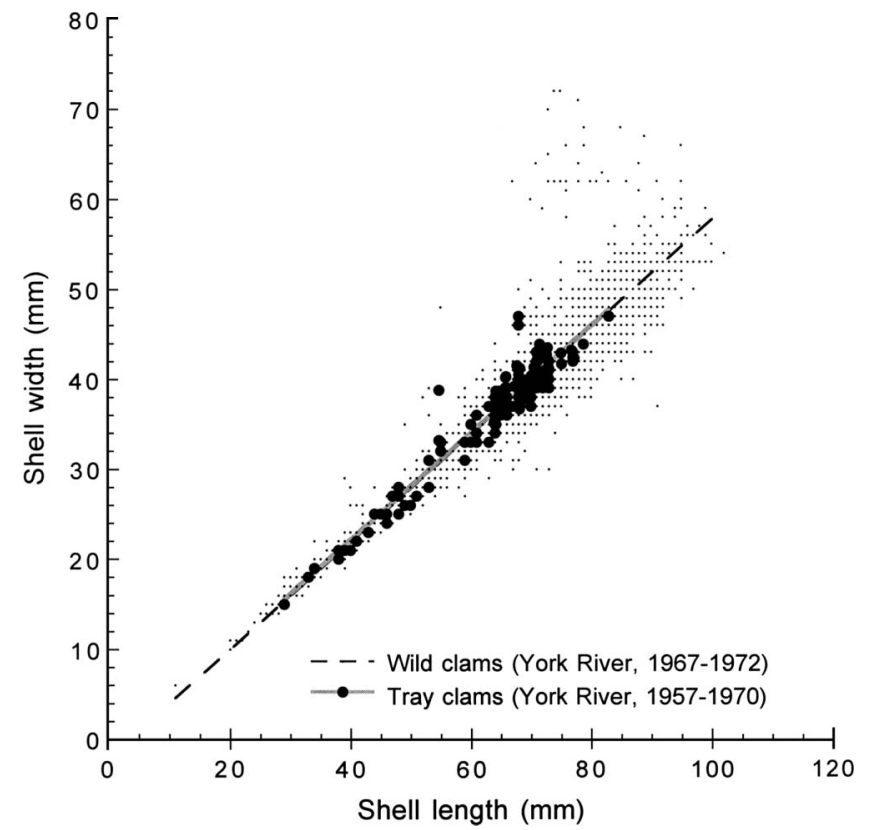

Figure 3. SL:SW relationships for tray grown $(1962$ to $1970, n=172$ measurements) and wild caught (1967 to $1972, n=2347$ clams) clams from the York River, Virginia. Regression equations for the fitted lines are: Tray: $\mathrm{SW}=-1.68+0.59 \mathrm{SL}, \mathrm{R}^{2}=0.93, n=172$ measurements of individuals $29-83 \mathrm{~mm}$ SL. Wild: $\mathrm{SW}=-2.02+0.59 \mathrm{SL}$, $\mathrm{R}^{2}=0.85, n=2342$ clams ranging from 11-102 $\mathrm{mm}$ SL.

decrease in growth increment for $M$. mercenaria collected in Narragansett Bay. This equation (Jones et al. 1989) is:

$$
\Delta \mathrm{SL}_{\mathrm{t}}=\mathrm{a} \times \mathrm{e}^{(-\mathrm{k} \times \mathrm{t})}
$$

where $\Delta \mathrm{SL}_{\mathrm{t}}$ is the annual change in shell length, $\mathrm{t}$ is the time in years, $\mathrm{e}$ is the base of the natural logarithm, $\mathrm{k}$ is the growth constant determined by curve fitting and $\mathrm{a}=\mathrm{k} \times \mathrm{SL}_{\max }$, where $\mathrm{SL}_{\max }$ is the maximum or asymptotic shell length determined by curve fitting.

A standardized shell length growth index (SGI, Jones et al. 1989) was calculated for each clam by dividing the observed annual shell length growth increment $\left(\Delta \mathrm{SL}_{\mathrm{t}}, \mathrm{mm}\right)$ by the expected annual shell length growth increment $\left(\Delta \mathrm{W}_{\mathrm{t}}, \mathrm{mm}\right)$. The expected annual growth increment was calculated by solving the fitted curve (Eq. 2) for each year for each clam. The observed annual growth increments were divided by the expected annual growth increments to calculate the standardized shell growth index (Jones et al. 1989):

$$
\mathrm{SGI}_{\mathrm{t}}=\Delta \mathrm{SL}_{\mathrm{t}} / \Delta \mathrm{W}_{\mathrm{t}}
$$

The average SGI ( \pm standard error of the mean) for each year was calculated from the individual clam data to describe the growth trajectory for these York River animals during the period 1955 through 1970. The annual average SGI in years for which 12 months of water temperature data were available was plotted in relation to the annual average sea surface temperature $\left({ }^{\circ} \mathrm{C}\right)$ for that year to evaluate the relationship between growth increment and water temperature conditions.

\section{RESULTS}

Annual surface water temperature $\left({ }^{\circ} \mathrm{C}\right)$ values at Gloucester Point, Virginia from 1954 through 1968 (Fig. 1) ranged from

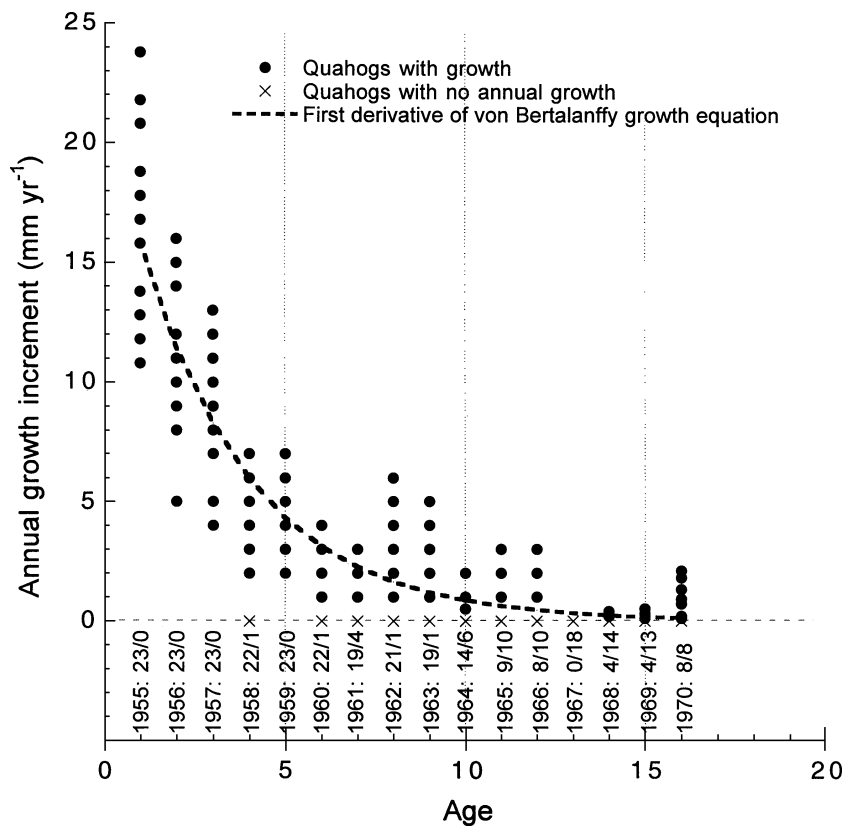

Figure 4. Annual growth increment $\left.\left(\mathrm{mm}^{-1}\right)^{-1}\right)$ observed for northern quahogs in the York River, VA from 1954 (Age 0) to 1970 (Age 16). Quahogs were kept at abundances of 125-145 clams tray ${ }^{-1}$ from 10/1954 through 10/1955 and 25 quahogs tray ${ }^{-1}$ or less from 11/1955 through 12/ 1970. The year is indicated above the age with the number of clams that grew (Quahogs with growth) in relation to the number of clams that showed no change in length (Quahogs with no growth) in that year (e.g., 1955: 23/0. The exponential relationship between age and annual growth increment was described by the first derivative of the Von Bertalanffy model. The equation is:

$$
\text { Annual growth increment }=21.99 \times e^{(-0.3257 \times-0.1807)}
$$

$4^{\circ} \mathrm{C}$ to $27^{\circ} \mathrm{C}$. Water temperatures observed in summer 1955 were higher $\left(28.5^{\circ} \mathrm{C}\right)$ than summer water temperatures during any other year in the period 1954 to 58 and 1960 to 1968 (Fig. 1). The winter of 1962 to 1963 was colder $\left(1.5^{\circ} \mathrm{C}\right)$ than other years in this period. No data were available for 1959 and 1969 to 1970.

Quahog shell length $(\mathrm{mm})$ increased with age (yr, Fig. 2A). Most of the growth in shell length occurred in the first 6 years with clams reaching shell lengths of $58 \mathrm{~mm}$ by November 1960 (Table 1, Fig. 2). The maximum observed individual shell length (84-mm SL) was recorded in June 1963 for a 9-year-old clam, which died between June 1963 and May 1964. After this individual died, maximum observed shell lengths were 77-78 $\mathrm{mm}$ until the end of the experiment in December 1970 (Table 1).

The coefficient of determination $\left(\mathrm{R}^{2}\right)$ for the Von Bertalanffy model was 0.93 with an $\mathrm{SL}_{\max }$ value of $67.54 \mathrm{~mm}$, $\mathrm{k}$ value of 0.3257 , and $t_{0}$ of -0.1807 . This $\mathrm{SL}_{\max }$ value may be somewhat skewed toward the lower size classes given the difference in numbers of small clams measured before (125-145 individual clams) and after (16-25 individual clams) November 1955 (Table 1).

In November 1955, one year after deployment, $88 \%$ of quahogs were still alive (Table 1). After quahogs were individually numbered and moved to lower densities, survivorship in the trays remained above $90 \%$ for the 25 animals placed in each tray in November 1955 and monitored until 1964 (80\% surviving), after which there was a steady annual decline until the experiment was ended in December 1970 with final survivorship of $64 \%$ over the 16 years monitored (Table 1 ). 


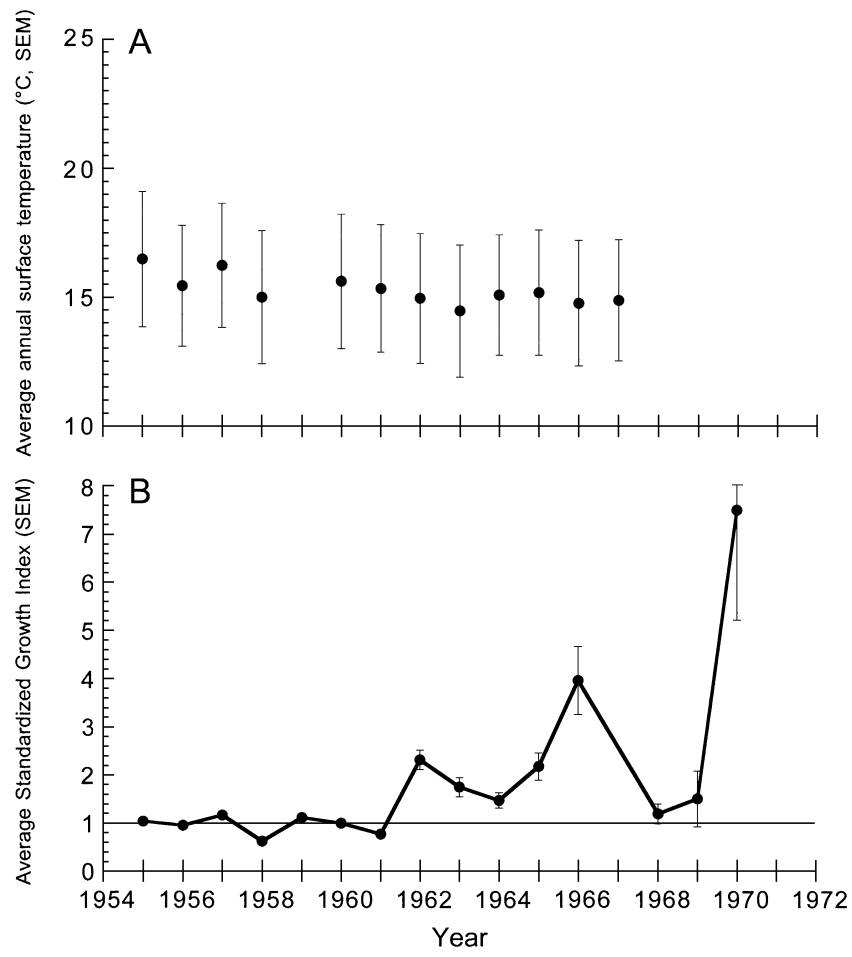

Figure 5. Average annual surface water temperature (A., ${ }^{\circ} \mathrm{C}$, standard error of the mean, SEM) and average standardized growth index (B., SEM) for York River northern quahogs for the period 1954 to 1970. Water temperature data were unavailable for 1959 and 1968 to 1970.

Shell length (SL): shell width (SW) relationships for tray clams and wild York River clams were both described with linear relationships (Fig. 3).

$$
\begin{aligned}
\text { Tray }: \mathrm{SW} & =-1.68+0.59 \mathrm{SL}, \mathrm{R}^{2}=0.93 \\
n & =172 \text { measurements of individuals } 29-83 \mathrm{~mm} \text { SL. }
\end{aligned}
$$

Wild : SW $=-2.02+0.59 \mathrm{SL}, \mathrm{R}^{2}=0.85$,

$$
n=2342 \text { clams ranging from 11-102 mm SL. }
$$

The slopes of both fitted lines were 0.59 indicating no difference in the SL:SW-relationship between clams grown in

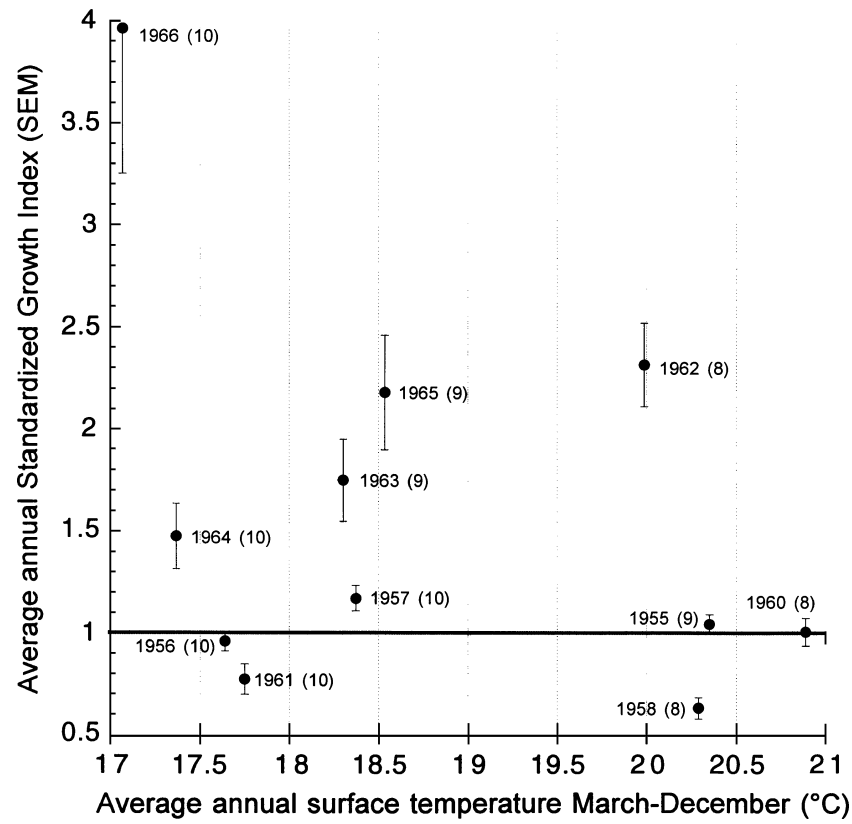

Figure 6. Average surface water temperature $\left({ }^{\circ} \mathrm{C}\right)$ during the growth period (March to November, water temperature above $7^{\circ} \mathrm{C}$ ) in relation to the average annual standardized growth increment for York River northern quahogs from 1955 to 1958 and 1960 to 1967. The number of months in each year with average surface temperatures above $7^{\circ} \mathrm{C}$ is indicated in parentheses after the year.

trays and wild clams from the York River. The average SL:SW ratio for tray clams was $1.76 \pm$ standard error of 0.01 . The average SL:SW ratio for York River wild clams was $1.77 \pm 0.01$. The ratios for York River animals are slightly less than the SL/SW ratio of 1.90 reported by Stanley and DeWitt (1983) but are consistent within the habitat of interest.

The observed annual SL growth increment decreased exponentially with quahog age (Fig. 4). The observed absence of growth in SL in 1967 (Fig. 4) may be real or may be a function of measurement error in that annual changes in SL for 13-year-old northern quahogs are expected to be on the order of tenths of $\mathrm{mm}$ (e.g., Ansell 1968, Walker \& Tenore 1984, Jones et al. 1989, this study). Slight errors in measurement may have translated into a lack of observed growth in SL during 1967 because the clams were measured by one group of individuals from 1954 to 1966

TABLE 2.

Comparison of age at length estimates for northern quahogs from selected sites along the northern quahog's latitudinal range.

SL $=$ shell length in mm. Age at length data from Kennish and Loveland (1980), Jones et al. (1989), and Jones et al. (1990) are estimated from shell heights (SH) using the morphological relationships for SL:SH from Stanley and DeWitt (1983).

\begin{tabular}{lccc}
\hline \hline \multicolumn{1}{c}{ Source } & Age 5 SL $(\mathbf{m m})$ & Age 10 SL $(\mathbf{m m})$ & Location \\
\hline Walker and Tenore 1984 & $50-60$ & $70-75$ & Wassaw Sound, GA \\
Jones et al. 1989 & $45-50$ & $60-65$ & Narragansett Bay, RI \\
Loesch and Haven 1973a & 51 & 70 & York River, VA \\
This study & $\mathbf{5 5}$ & $\mathbf{6 5}$ & York River, VA \\
Ropes 1987 & $50-70$ & $68-90$ & Raritan Bay, NJ \\
Eversole et al. 1986 & $55-65$ & No Data. & Clark Sound, SC \\
Jones et al. 1990 & $55-65$ & $65-80$ & Florida and Georgia \\
Kennish and Loveland 1980 & 63.61 & No Data. & Barnegat Bay, NJ \\
\hline
\end{tabular}


and a second, different group of individuals from 1967 to 1970 with the 1967 measurement as the transition from one group to the other. Observed annual surface water temperature conditions in 1967 were similar to those observed during 1955 to 1966 (Fig. 1, Fig. 5A).

Standardized growth index values of 1 are indicative of a balance between expected and observed growth in SL (Jones et al. 1989). SGI values above 1 represent years of better than expected growth while SGI values less than 1 demonstrate years with less than expected shell growth. SGI values for these York River northern quahogs varied between 1954 and 1970 (Fig. 5). Eleven of the 15 years for which data are available were better than expected (SGI $>1$ ) growing years with three years showing less than expected growth (SGI < 1, 1955, 1958, and 1961) and the remaining year showing expected growth $(\mathrm{SGI}=1,1960)$. There was no clear relationship between SGI and average annual surface temperature (Fig. 5) or average growth period surface temperature (Fig. 6) for the average growth surface temperature range $\left(17-21.0^{\circ} \mathrm{C}\right)$ observed in the York River between 1955 and 1967 (no water temperature data were available for 1959 or 1968 to 1970). It is interesting to note that the three years with annual SGI values less than 1 correspond to years in which the preceding winter was colder than other years (1956, 1958, 1961; Figs.1 and 6) although the duration of the growing season was not atypical (8-10 months as for other years, Fig. 6).

\section{DISCUSSION}

Northern quahogs in the York River, Virginia, during the period 1954 to 1970 achieved maximum SLs of 77-84 mm and displayed an ontogenetic decline in SL growth. The observed maximum SL for 16-yr-old northern quahogs in this study of $77-78 \mathrm{~mm}$ SL are equal to the $\mathrm{SL}^{\max }$ estimated for wild York River clams during 1967-1970 (77 mm for age 16) by Loesch and Haven (1973a). These tray clams were larger or of equal size to clams planted in adjacent bottom habitats after 2 years (1954-1956, Haven \& Andrews 1957). The observed annual SL growth increment for a $40 \mathrm{~mm}$ SL quahog $(2.75 \mathrm{yr}$ old, Fig. 1A; $9 \mathrm{~mm} \mathrm{yr}^{-1}$, Fig. 3) is less than the growth increment reported by Ansell (1968) for North Carolina clams (12-15 $\mathrm{mm} \mathrm{yr}^{-1}$ ) but within the range of growth predicted for New Jersey clams (2-15 $\mathrm{mm} \mathrm{yr}^{-1}$, Ansell 1968). These differences are not surprising given latitudinal and temperature differences that directly influence the duration of the annual growth period for northern quahogs (Ansell 1968, Grizzle et al. 2001).

The relatively high quahog densities in the holding trays may have slowed individual growth rates. Quahog densities for early grow out in this study (November 1954 to October 1955) were approximately $1500 \mathrm{~m}^{-2}$, whereas densities from November 1955 onward were decreased to $269 \mathrm{~m}^{-2}$. Eldridge et al. (1979) showed that clams at densities of $290 \mathrm{~m}^{-2}$ grew faster than clams at higher densities (869 and 1,159 clams $\mathrm{m}^{-2}$ ). Reducing holding densities in October 1955 should have reduced the effects on subsequent growth rates. In any case, tray densities were at least an order of magnitude higher than densities of wild clam populations in the York River surveyed

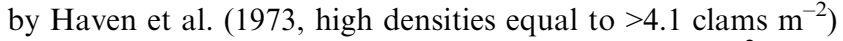
and, more recently, by Mann et al. (2005, 4-8 clams $\mathrm{m}^{-2}$ ).

The potential effects of tray culture at these densities on quahog morphology are assumed to be negligible given that these clams had the same slope for the SL:SW relationship as wild York river clams collected during 1967 to 1972 by Haven et al. (1973). Blunting, the thickening of the ventral growth margin accompanying a decrease in SL, was observed during 1967 to 1972 at sites in the York River within 1-10 km of the VIMS pier by Loesch and Haven (1973a) and was attributed to low salinity and shallow water (depths $<3 \mathrm{~m}$ ). Blunting is typically visible on the interior of the shell valves and it is unknown if any of the tray clams were examined and classified as blunted when the experiment was terminated in December 1970.

The age at length relationship observed for northern quahogs grown in trays in the York River, Virginia during 1954 to 1970 predicts SLs of 55 and $65 \mathrm{~mm}$ at ages of 5 and $10 \mathrm{yrs}$, respectively. These age-at-length estimates are within the range of previous estimates of age-at-length relationships for wild clams (Table 2) recorded at sites along the latitudinal range of northern quahogs.

\section{ACKNOWLEDGMENTS}

The author thanks those who set up this growth experiment and maintained it from 1954 to 1970 notably Dexter S. Haven, Jay D. Andrews, James Whitcomb, and Kenneth Walker. Reinaldo Morales-Alamo archived all of the original project datasheets. Roger Mann and Melissa Southworth offered helpful comments on an earlier version of this manuscript. This is Contribution Number 2806 from the Virginia Institute of Marine Science, Gloucester Point, Virginia.

\section{LITERATURE CITED}

Andrews, J. D. 1996. History of Perkinsus marinus, a pathogen of oysters in Chesapeake Bay 1950-1984. J. Shellfish Res. 15:13-16.

Ansell, A. 1968. The rate of growth of the hard clam Mercenaria mercenaria $(\mathrm{L})$ throughout the geographic range. J. Cons. Perm Int. explor. Mer. 31:364-409.

Burreson, E. \& L. Calvo. 1996. Epizootiology of Perkinsus marinus disease of oysters in Chesapeake Bay, with emphasis on data since 1985. J. Shellfish Res. 15:17-34.

Devillers, N., A. Eversole \& J. Isely. 1998. A comparison of four growth models for evaluating the growth of the northern quahog Mercenaria mercenaria (L.). J. Shellfish Res. 17:191-194.

Eldridge, P., A. Eversole \& J. Whetstone. 1979. Comparative survival and growth rates of hatchery seed clams Mercenaria mercenaria, in protected trays in waters of South Carolina. Proc. Nat. Shellfish. Assoc. 66:13-20.

Eversole, A., L. Grimes \& P. Eldridge. 1986. Variability in growth of hard clams, Mercenaria mercenaria. Amer. Malacol. Bull. 4:149155 .

Grizzle, R., V. Bricelji \& S. Shumway. 2001. Physiological ecology of Mercenaria mercenaria. In: J. Kraeuter \& M. Castagna, editors. Biology of the hard clam. The Netherlands: Elsevier Science B.V. pp. 305-382.

Haven, D. S. \& J. D. Andrews. 1957. Survival and growth of Venus mercenaria, Venus campechiensis, and their hybrids in suspended trays and on natural bottoms. Proceedings of the National Shellfisheries Association. 47. pp. 43-49. 
Haven, D., J. Loesch \& J. Whitcomb. 1973. An investigation into commercial aspects of the hard clam fishery and development of commercial gear for the harvest of molluscs. Final Rep. 3-124-R, US Dept. of Commerce, Nat. Mar. Fish. Serv. Comm. Fish. Res. Develop. Act 88-309.

Jones, D., M. Arthur \& D. Allard. 1989. Sclerochronological records of temperature and growth from shells of Mercenaria mercenaria from Narragansett Bay, Rhode Island. Mar. Biol. 102:225-234.

Jones, D., I. Quitmyer, W. Arnold \& D. Marelli. 1990. Annual shell banding, age, and growth rate of hard clams (Mercenaria spp.) from Florida. J. Shellfish Res. 9:215-225.

Kennish M. \& R. Loveland. 1980. Growth models of the northern quahog Mercenaria mercenaria (Linne). Proc. Nat. Shellfish. Assoc. 70:230-239.

Loesch, J. G. \& D. S. Haven. 1973a. Estimated growth functions and size-age relationships of the hard clam, Mercenaria mercenaria, in the York River, Virginia. Veliger 16:76-81.

Loesch, J. G. \& D. S. Haven. 1973b. Estimates of hard clam abundance from hydraulic escalator samples by the Leslie method. Chesapeake Sci. 14:215-216.

Mann, R., J. M. Harding, M. J. Southworth \& J. Wesson. 2005. Hard clam Mercenaria mercenaria abundance and habitat use in Chesapeake Bay, USA. J. Shellfish Res. 24:509-516.

Ropes, J. 1987. Age and growth, reproductive cycle, and histochemical tests for heavy metals in hard clams, Mercenaria mercenaria, from Raritan Bay, 1974-1975. Fish. Bull. U.S. 85:653-662.
Roegner, G. C. \& R. Mann. 1991. The hard shell clam. In: J. A. Funderburk, S. Mihursky. J. Jordan \& D. Riley, eds. Habitat requirements for Chesapeake Bay living resources. Annapolis, MD: SU.S.F.W.S.

Stanley, J. \& R. DeWitt. 1983. Species profiles: life histories and environmental requirements of coastal fishes and invertebrates (North America) - hard clam. US Fish and Wildlife Service. FWS OBS-82/11.18. $19 \mathrm{pp}$.

United States Department of Commerce. 1960. Surface water temperature and density: Atlantic coast North and South America. Coast and Geodetic Survey, C \& GS Publication 31-1, 1st ed. $76 \mathrm{pp}$.

United States Department of Commerce. 1968. Surface water temperature and density: Atlantic coast North and South America. Environmental Science Services Administration, Coast and Geodetic Survey, C \& GS Publication 31-1, 3rd ed. 102 pp.

United States Department of Commerce. 1973. Surface water temperature and density: Atlantic coast North and South America. National Oceanic and Atmospheric Administration, National Ocean Survey. NOS Publication 31-1, 4th. $109 \mathrm{pp}$.

Walker, R. \& K. Tenore. 1984. The distribution and production of the hard clam, Mercenaria mercenaria, in Wassaw Sound, Georgia. Estuaries. 7:19-27. 